\title{
Reassessing the death risk related to probiotics in critically ill patients
}

\author{
Alberto Enrico Maraolo \\ See related research by Manzanares et al., https://ccforum.biomedcentral.com/articles/10.1186/s13054-016-1434-y \\ This comment refers to the article available at: http://dx.doi.org/10.1186/s13054-016-1434-y.
}

Manzanares and colleagues, in their very comprehensive systematic review with meta-analysis [1], conclude that probiotics prove to be a very useful weapon to reduce infections in critically ill patients, although strong recommendation in support of their use cannot be drawn yet. Indeed, they correctly state that publication bias and heterogeneity of the included studies could undermine their conclusions [1]. Another relevant aspect of the paper is the safety profile of probiotics, a well-known matter of debate: no effect was observed upon length-ofstay, diarrhea, and, most of all, mortality [1].

With regard to this crucial point, Fig. 3 in [1] describes the overall effect on hospital mortality, with a risk ratio equal to 0.98 (95\% confidence interval $0.82-1.18$ ); obviously the result is not significant but the direction of the effect is in favour of probiotics. It is worth underlining that their Fig. 3 reports a wrong datum about the mortality in the trial by Besselink and colleagues [2], that is 24 out of 152 patients (as correctly reported in Table 2) and not 14 out of 152 in the probiotics arm.

Reassessing the risk ratio with the meta-analytic software ProMeta 3.0, the overall effect becomes 1.02 (95\% confidence interval $0.85-1.22$ ), changing the direction of the effect against the use of probiotics, although the result is not significant. The weight of the results stemming from the trial by Besselink and colleagues [2] is, for example, clearly apparent in another systematic review with metaanalysis published in Critical Care in 2014 [3].

In spite of their clinical use for a long time, the exact role of probiotics in many therapeutic settings is still not clear, and safety issues in special populations (pregnant women, immunosuppressed, severe underlying diseases) are the main matter of concern [4]. To this purpose, providing the most precise information is fundamental to support clinicians' decisions.
Acknowledgements

Not applicable.

Funding

No funding was needed for this letter.

Availability of data and materials

Not applicable.

Authors' contributions

AEM was personally responsible for both the writing and revision of the article.

\section{Competing interests}

The authors report no potential conflicts of interest with any companies/ organizations whose products may be discussed in this manuscript.

Consent for publication

Not applicable.

Ethics approval and consent to participate

Not applicable.

Published online: 29 November 2016

References

1. Manzanares $W$, Lemieux M, Langlois PL, Wischmeyer PE. Probiotic and synbiotic therapy in critical illness: a systematic review and meta-analysis. Crit Care. 2016;20:262.

2. Besselink MG, van Santvoort HC, Buskens $E$, Boermeester MA, van Goor $H_{\text {, }}$ Timmerman HM, Nieuwenhuijs VB, Bollen TL, van Ramshorst B, Witteman BJ, Rosman C, Ploeg RJ, Brink MA, Schaapherder AF, Dejong CH, Wahab PJ, van Laarhoven CJ, van der Harst E, van Eijck CH, Cuesta MA, Akkermans LM, Gooszen HG, Dutch Acute Pancreatitis Study Group. Probiotic prophylaxis in predicted severe acute pancreatitis: a randomised, double-blind, placebo-controlled trial. Lancet. 2008;371:651-9.

3. Gou S, Yang Z, Liu T, Wu H, Wang C. Use of probiotics in the treatment of severe acute pancreatitis: a systematic review and meta-analysis of randomized controlled trials. Crit Care. 2014;18:R57.

4. Doron S, Snydman DR. Risk and safety of probiotics. Clin Infect Dis. 2015;60(S2):S120-34 